\title{
Priming Duration Influences Anatomy and Germination Responses of Parsley Mericarps
}

\author{
Michael Olszewski, Wallace Pill, and Thompson D. Pizzolato \\ University of Delaware, Department of Plant and Soil Sciences, Newark, DE 19717-1303 \\ John Pesek \\ University of Delaware, Department of Food and Resource Economics, Newark, DE 19717-1303
}

AdDitional INDEX words. Apiaceae, embryo, endosperm, seed treatment, Umbelliferae

\begin{abstract}
Germination studies indicated that increasing priming duration $\left(-1.0 \mathrm{MPa}\right.$ at $20{ }^{\circ} \mathrm{C}$ for 7 , 14, or 21 days) increased 'Moss Curled' parsley [Petroselinum crispum (Mill.) Nyman ex A.W. Hill] germination rate quadratically and seed moisture content linearly. A histological and anatomical study was conducted to identify and/or quantify principle mericarp organ or tissue volume changes influenced by priming duration. Embryo volume increased as priming duration increased from 7 to 21 days $\left(0.014\right.$ to $\left.0.034 \mathrm{~mm}^{3}\right)$, and this was due more to radicle $\left(0.007\right.$ to $\left.0.022 \mathrm{~mm}^{3}\right)$ than to cotyledon $\left(0.006\right.$ to $\left.0.011 \mathrm{~mm}^{3}\right)$ growth. Concomitant with increased embryo volume was increased volume of the depleted layer (space formation, surrounding the embryo), from 0.038 after 7 days to $0.071 \mathrm{~mm}^{3}$ after 21 days, and increased hydrolysis of central endosperm (a thick-walled endosperm type). In nonprimed mericarps, central endosperm cells constituted $97 \%$ of the endosperm volume. The remaining $3 \%$ was comprised of $1 \%$ depleted layer and $\mathbf{2 \%}$ distal endosperm (small, thin-walled, and irregularly shaped endosperm cells). During 7 or 21 days of priming, $\approx \mathbf{1 0} \%$ or $\mathbf{4 0 \%}$, respectively, of central endosperm cells were hydrolyzed centrifugally around the embryo with a corresponding decrease in volume of central endosperm with thick cell walls. In addition, distal endosperm cells adjacent to the depleted layer, containing reserve materials, were digested of contents following 21 days priming, and sometimes, following 7 days priming. A long priming duration resulted in degradation of pericarp tissues, as indicated visually and by a decline in pericarp volume. We hypothesize that priming duration of parsley primarily influences radicle growth and centrifugal digestion and utilization of central and distal endosperm, resulting in a larger depleted layer required for embryo volume increases. Secondary events influenced by priming duration include cotyledon growth and degradation of pericarp tissues.
\end{abstract}

Seed priming is their exposure to sufficiently low water potentials to permit hydration but prevent radicle protrusion (see review by Pill, 1995). Priming of parsley mericarps (-1.2 MPa for 3 weeks at $15^{\circ} \mathrm{C}$ ) gave greater, earlier and more synchronous emergence (Ely and Heydecker, 1981). Pill (1986) noted that this same priming treatment gave earlier emergence and greater seedling shoot fresh weights but had no effect on emergence percentage of parsley. Akers et al. (1987), likewise, noted that priming $\left(-0.5 \mathrm{MPa}\right.$ for $3 \mathrm{~d}$ at $25^{\circ} \mathrm{C}$, then $-0.8 \mathrm{MPa}$ for $\left.1.5 \mathrm{~d}\right)$ speeded germination but had no effect on emergence synchrony or percentage. Embryo growth during priming (Dawidowicz-Grzegorzewska and Maguire, 1993; Gray et al., 1990; van der Toorn, 1989), and loosening of endosperm that is restrictive to embryo growth (Argerich and Bradford, 1989; Dahal et al., 1990; Guedes et al., 1981; Liptay and Zariffa, 1993; van der Toorn, 1989) were associated with increased germination rate of primed seed.

Austin et al. (1969) determined that carrot (Daucus carota L.) embryo length and volume increased after successive short duration water hydration treatments. Embryo volume of carrot (Gray et al., 1990) and parsley (Olszewski et al., 2004), and celery (Apium graveolens L.) embryo length (van der Toorn, 1989) increased as a result of priming. Embryo length increased with longer seed priming durations of carrot (Dawidowicz-Grzegorzewska and Maguire, 1993) or celery (van der Toorn, 1989).

Seed priming of lettuce (Lactuca sativa L.; Guedes et al., 1981) or tomato (Lycopersicon esculentum Mill.; Dahal et al., 1990) resulted in progressive loosening of endosperm tissue. Priming caused endosperm degradation at the distal end of car-

Received for publication 4 Feb. 2005. Accepted for publication 21 Mar. 2005. rot (Dawidowicz-Grzegorzewska, 1997) and celery (van der Toorn, 1989) mericarps. In response to priming of tomato seeds, a cavity formed around the cotyledons, and both seed volume and endosperm weakening increased (Argerich and Bradford, 1989). Liptay and Zariffa (1993) noted that priming of tomato seeds increased radicle growth and endosperm degradation. In earlier work we noted that increased germination percentage, rate, and synchrony of primed parsley mericarps $(-1.0 \mathrm{MPa}$ for $7 \mathrm{~d}$ at $20^{\circ} \mathrm{C}$ ) was associated with a doubling of radicle and cotyledon volumes and greater endosperm depletion adjacent to the embryo (Olszewski et al., 2004). Extending the priming duration from 4 to $7 \mathrm{~d}$ further increased the germination rate of parsley mericarps (Pill and Killian, 2000). The objective of this study was to identify and quantify anatomical changes influenced by priming duration of parsley mericarps, and relate these changes to germination performance.

\section{Materials and Methods}

Priming and germination. Parsley 'Moss Curled' mericarps (single-seeded dispersal unit of the schizocarp) and schizocarpic fruits were purchased as a single seed lot (Carolina Seeds, Boone, N.C.). Mericarps were separated from the schizocarps prior to seed testing and single mericarps were used for experiments within 6 months of purchase. Mericarps were primed in $125 \times$ $80 \times 20$-mm transparent polystyrene boxes containing two layers of germination blotters (germination blotter No. 385; Seedburo, Chicago) and moistened with $15 \mathrm{~mL}$ polyethylene gylcol (PEG $6000)$ at $284 \mathrm{~g}^{\cdot} \mathrm{L}^{-1}$, equivalent to a nominal water potential of $-1.0 \mathrm{MPa}$ (Michel and Kaufmann, 1973). Priming was conducted in darkness at $20^{\circ} \mathrm{C}$ for 0 (nonprimed), 7, 14, or $21 \mathrm{~d}$. Each box 
contained $\approx 1 \mathrm{~g}(\approx 500$ mericarps $)$ mericarps spread as a single layer. To assure constant water potential, solutions were changed every 24 to $48 \mathrm{~h}$ during priming. During each change, mericarps were vacuum-surface dried before transferring to new blotters and PEG solution. After priming, mericarps were triple-rinsed in deionized water to remove PEG, and then dried at $21^{\circ} \mathrm{C}$ and $45 \%$ relative humidity $(\mathrm{RH})$ with air-flow for $7 \mathrm{~d}$ to seed moisture between $9.5 \%$ and $10.5 \%$. Seed moisture, expressed on a fresh weight basis, was determined on three replicates of $0.2-\mathrm{g}$ mericarps after oven-drying at $130^{\circ} \mathrm{C}$ for $1 \mathrm{~h}$ (International Seed Testing Assn., 1985).

The germination assay was conducted in darkness at constant $20{ }^{\circ} \mathrm{C}$. Nonprimed or primed mericarps were distributed onto double thickness germination blotters (germination blotter No. $385)$ saturated with $15 \mathrm{~mL}$ deionized water contained in $125 \times$ $80 \times 20-\mathrm{mm}$ transparent polystyrene boxes. Each box (treatment) contained 50 mericarps, with four replications arranged in a completely randomized design. Germination (mericarps with visible radicles) was counted daily and germinated seeds removed from the box. From these counts, the angular transformation (arcsin of the square root) of final germination percentage (FGP) and days to $50 \% \mathrm{FGP}\left(\mathrm{G}_{50}\right.$, an inverse measure of germination rate) were calculated and subjected to analysis of variance.

MericarP ANATOMY. A histological protocol similar to that of Jensen (1962) was used. Eight nonprimed mericarps and eight 7-d- or 21-d-primed mericarps were soaked in $10 \%$ buffered formalin phosphate for 2.5 weeks. To aid chemical infiltration, mericarps were cut transversely and centrally with a razor blade. Dehydration under vacuum used a $70 \%$ to $100 \%$ ethanol series followed by xylene infiltration, also under vacuum. Infiltration with paraffin was under vacuum for 8 to $12 \mathrm{~d}$. Transverse sections were cut with an M1R rotary microtome (Shandon, Pittsburgh) at a setting of $6 \mu \mathrm{m}$; however, actual section thickness was estimated to be $7.1 \mu \mathrm{m}$ using the "fold-method" (Bozzola and Russell, 1992). Sections were deparaffinized, stained with $0.5 \%$ safranin followed by $0.5 \%$ fast green, and permanently mounted.

Mericarp organ or tissue lengths were determined by multiplying section thickness by the number of transverse sections included in a given organ or tissue. Organ or tissue area was estimated on every fifth serial section by tracing its outline projected through a drawing tube attached to a Wild M20 microscope (Martin Microscope Co., Easley, S.C.), followed by referencing to a $0.25-\mathrm{mm}^{2}$ standard determined using a cut and weigh method (Bozzola and Russell, 1992). Each mericarp organ or tissue volume was calculated using the equation $\mathrm{V}_{\mathrm{o}}=\left(\Sigma \mathrm{a}_{\mathrm{e}}\right) \mathrm{t}$, where $\mathrm{V}_{\mathrm{o}}=$ mericarp organ or tissue volume; $\mathrm{a}_{\mathrm{e}}=$ tissue area; and $\mathrm{t}=$ paraffin section thickness.

\section{Results and Discussion}

Priming and germination. Priming had no effect on germination percentage $($ mean $=86 \%)$ but decreased the $\mathrm{G}_{50}$ (Table 1$)$. Increased germination rate is a common response to priming of parsley (Akers et al, 1987; Olszewski et al, 2004; Pill and Kilian, 2000). Increasing duration of priming resulted in a quadratic decrease in $\mathrm{G}_{50}$, with most of the decrease occurring between 7 and 14 d. Pill and Kilian (2000) had noted decreased $\mathrm{G}_{50}$ as parsley priming increased from 4 to $7 \mathrm{~d}$. A linear increase in seed moisture contents $(41.0 \%, 42.9 \%$, and $43.6 \%$ for 7,14 , and $21 \mathrm{~d}$ priming) was associated with decreasing $\mathrm{G}_{50}$ as priming duration increased. Brocklehurst and Dearman (1984) noted similar moisture contents of primed $\left(-1.5 \mathrm{MPa}\right.$ for 2 weeks at $\left.15^{\circ} \mathrm{C}\right)$ mericarps of carrot
Table 1. Final germination percentage (FGP), days to $50 \%$ FGP $\left(\mathrm{G}_{50}\right)$, and mericarp moisture of nonprimed and primed $(7,14$, or $21 \mathrm{~d}$ at 20 ${ }^{\circ} \mathrm{C}$ and $-1.0 \mathrm{MPa}$ ) mericarps of 'Moss Curled' parsley.

\begin{tabular}{|c|c|c|c|}
\hline $\begin{array}{l}\text { Mericarp } \\
\text { treatment }\end{array}$ & $\mathrm{FGP}^{\mathrm{z}}$ & $\begin{array}{l}\mathrm{G}_{50} \\
\text { (d) }\end{array}$ & $\begin{array}{l}\text { Mericarp moisture } \\
\text { (\% fresh wt) }\end{array}$ \\
\hline Nonprimed & $88 \%\left(70^{\circ}\right)$ & 7.6 & 7.5 \\
\hline Primed, $7 \mathrm{~d}$ & $83 \%\left(66^{\circ}\right)$ & 4.5 & 41.0 \\
\hline Primed, $14 \mathrm{~d}$ & $86 \%\left(69^{\circ}\right)$ & 2.7 & 42.9 \\
\hline Primed, $21 \mathrm{~d}$ & $87 \%\left(69^{\circ}\right)$ & 2.5 & 43.6 \\
\hline $\operatorname{LSD}_{0.05^{\mathrm{y}}}$ & $\left(8^{\circ}\right)$ & $(0.3)$ & 1.2 \\
\hline \multicolumn{4}{|l|}{ Significance } \\
\hline Mericarp treatment & (NS) & $* * *$ & $* * *$ \\
\hline Priming, linear & (NS) & $* * *$ & $* * *$ \\
\hline Priming, quadratic & (NS) & $* *$ & NS \\
\hline
\end{tabular}

${ }^{\mathrm{z}}$ Angular transformation (arcsin square root).

yLeast significant difference, $P \leq 0.05$.

NS, ${ }^{* *}, * * *$ Nonsignificant or significant at $P \leq 0.001$ or 0.01 , respectively.

$(39.2 \%)$, celery $(36.8 \%)$, leek (Allium porrum L., $46.9 \%)$, and onion (A. серa L., $41.2 \%$ ). Increased seed moisture content with priming duration may be due to osmotic adjustments necessary for effective priming (Bradford, 1986).

Mericarp ANATOMY. Radicles were the primary source of embryo growth during priming, although cotyledon growth also occurred (Fig. 1A-C and Table 2). A large increase in radicle diameter was observed as priming duration increased (Fig. 1D-F). For nonprimed, 7-d-primed, and 21-d-primed mericarps, respective radicle volumes were $0.005,0.007$, and $0.022 \mathrm{~mm}^{3}$, while respective cotyledon volumes were $0.004,0.006$, and $0.011 \mathrm{~mm}^{3}$. An increase in priming duration ( 0 to $8 \mathrm{~d}$ ) resulted in increased embryo length of carrot (Dawidowicz-Grzegorzewska and Maguire, 1993). Higher priming osmotic potential and longer priming duration resulted in increased celery embryo length (van der Toorn, 1989). In earlier work (Olszewski et al., 2004), we established that parsley embryo volume, but not length, increased with $7 \mathrm{~d}$ priming. We believe that this is the first report showing a direct relationship between priming duration and radicle and cotyledon volumes.

Surrounding the embryo is the depleted layer which is a space containing no endosperm cells or cell remnants (Fig. 1A-F). Primed mericarps had greater depleted layer volume than nonprimed mericarps, and increasing the priming duration increased the depleted layer volume (Table 2). Depleted layer volumes for nonprimed mericarps, 7-d-primed mericarps, and 21-d-primed mericarps were $0.021,0.038$, and $0.071 \mathrm{~mm}^{3}$, respectively. Argerich and Bradford (1989) hypothesized that free space formation around the embryo was beneficial to germination because it allowed increased water uptake and greater turgor pressure, resulting in weakening of embryo restrictive endosperm tissues. In the present study, mericarp moisture content (Table 1) and depleted layer volume (Table 2 ) both increased with increased priming duration.

Exocarp and mesocarp tissues (Fig. 1B) of the pericarp were increasingly degraded as priming duration increased to $21 \mathrm{~d}$ (Fig. 1C). Pericarp and seed coat tissues contained sclerified cells (identified by intense staining with safranin red) at the distal end of the mericarp, which could provide a barrier to radicle protrusion. Pericarp, as a percentage of mericarp volume, was $46 \%, 44 \%$, and $26 \%$ for nonprimed, 7 -d-primed, and 21-d-primed mericarps. Pericarp volumes were $1.469,1.046$, and $0.612 \mathrm{~mm}^{3}$, respectively, for nonprimed, 7-d-primed, and 21-d-primed mericarps (Table 2 ). This indicated that 7 -d priming did not greatly affect pericarp volume while 21-d priming resulted in considerable loss of tissue. 

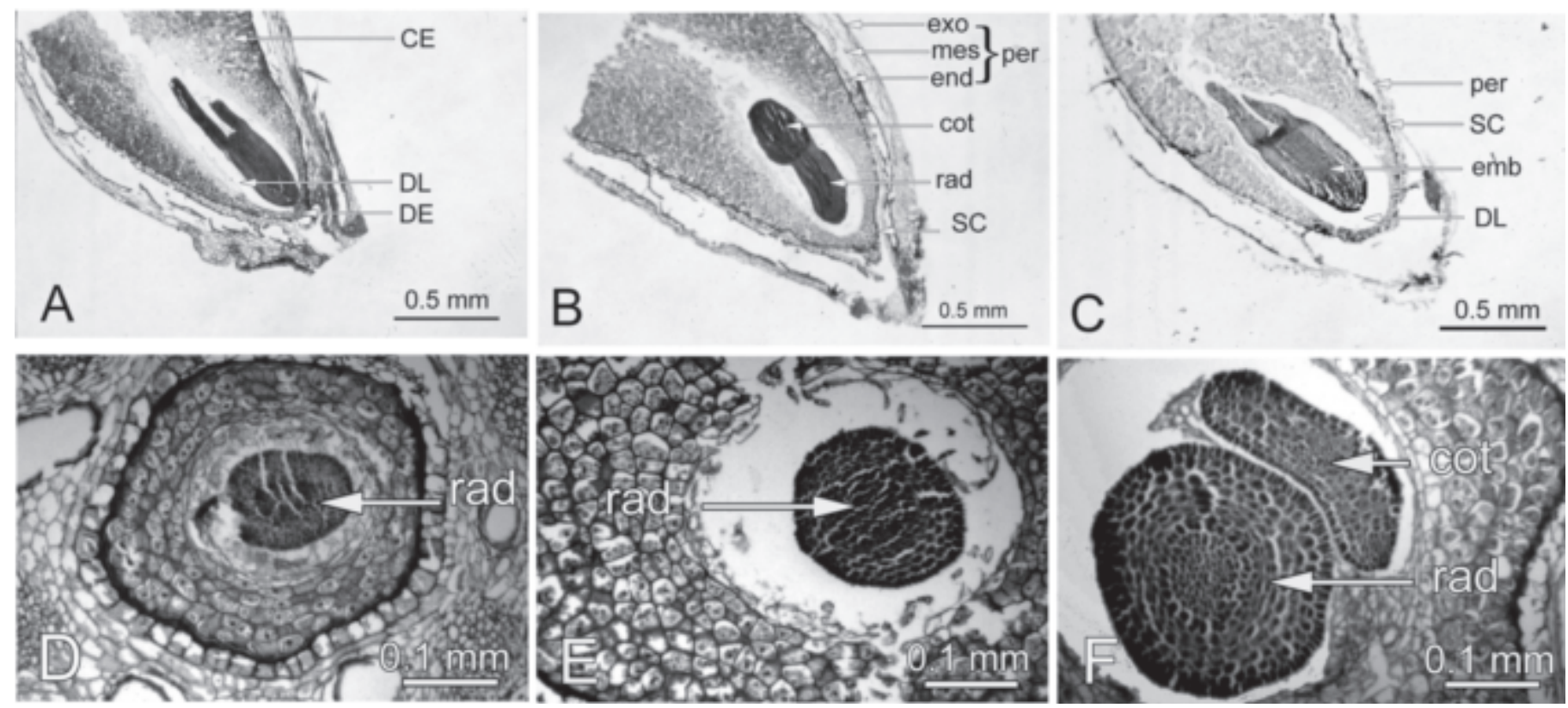

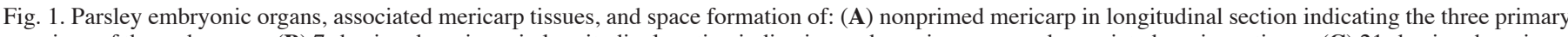

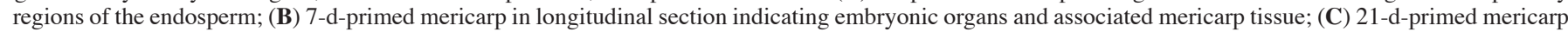

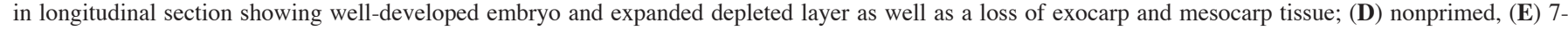

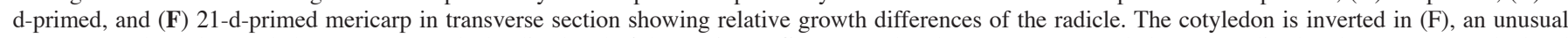

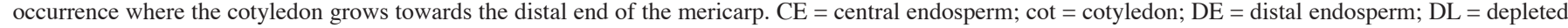
layer; emb = embryo; end = endocarp; exo = exocarp; mes = mesocarp; per = pericarp; rad $=$ radicle; $\mathrm{SC}=$ seedcoat

Table 2. Organ or tissue volumes of nonprimed or primed ( 7 or $21 \mathrm{~d}$ at $20{ }^{\circ} \mathrm{C}$ and $\left.-1.0 \mathrm{MPa}\right)$ 'Moss Curled' parsley mericarps.

\begin{tabular}{|c|c|c|c|}
\hline \multirow[b]{2}{*}{$\begin{array}{l}\text { Mericarp organ } \\
\text { or tissue }\end{array}$} & \multicolumn{3}{|c|}{ Mericarp treatment } \\
\hline & Nonprimed & $\begin{array}{l}\text { Primed } \\
\text { for } 7 \mathrm{~d}\end{array}$ & $\begin{array}{l}\text { Primed } \\
\text { for } 21 \mathrm{~d}\end{array}$ \\
\hline & \multicolumn{3}{|c|}{ Organ or tissue volume $\left[\text { mean } \pm S E\left(\mathrm{~mm}^{3}\right)\right]^{z}$} \\
\hline Embryo & $0.009 \pm 0.002$ & $0.014 \pm 0.002$ & $0.034 \pm 0.006$ \\
\hline Cotyledon & $0.004 \pm 0.001$ & $0.006 \pm 0.001$ & $0.011 \pm 0.002$ \\
\hline Radicle & $0.005 \pm 0.001$ & $0.007 \pm 0.001$ & $0.022 \pm 0.005$ \\
\hline Endosperm (total)y & $1.674 \pm 0.056$ & $1.279 \pm 0.117$ & $1.665 \pm 0.149$ \\
\hline Central endosperm & $1.629 \pm 0.059$ & $1.136 \pm 0.104$ & $0.979 \pm 0.272$ \\
\hline Depleted layer & $0.021 \pm 0.005$ & $0.038 \pm 0.006$ & $0.071 \pm 0.011$ \\
\hline Pericarp & $1.469 \pm 0.171$ & $1.046 \pm 0.083$ & $0.612 \pm 0.127$ \\
\hline
\end{tabular}

$\mathrm{z}_{\mathrm{n}}=8$.

yTotal endosperm $=$ depleted layer + central endosperm with thick cell walls + residual endosperm.

Parera et al. (1993) also noted pericarp degradation in primed celery. Parsley germination inhibitors (Kato et al., 1978) occur in seed coverings and can be removed by scarification (Hassell and Kretchmen, 1997). This study is thought to be the first to quantify loss of pericarp and relate it to priming duration.

In nonprimed mericarps, central endosperm comprised $97 \%$ of the total endosperm volume; the remaining $1 \%$ was depleted layer and 2\% was distal endosperm (Table 2). Thick-walled endosperm, a type of endosperm found in monocotyledonous and dicotyledonous seed, usually serves as a carbohydrate reserve for the developing embryo (Werker, 1997) and are characterized by having thick-walled endosperm type with distinct middle lamellae (Fig. 2A). In contrast to central endosperm, distal endosperm cells were small with thinner cell walls (Fig. 2B-C) and occurred at the micropylar region as well as regions flanking the radicle. Following 7- and 21-d priming, respectively, central endosperm with thick cell walls (Fig. 2A) declined to $\approx 90 \%$ and $60 \%$ of the total endosperm volume (with $10 \%$ and $40 \%$ with digested cell walls) while the depleted layer increased to $3 \%$ and $4 \%$ of the total endosperm volume (Table 2). Loss of central endosperm was quantified by determining remaining volume of thickwalled endosperm, which comprised 1.629, 1.136, and 0.979 $\mathrm{mm}^{3}$ in nonprimed, 7-d-primed, and 21-d-primed mericarps, respectively (Table 2). Although length differences for whole mericarps were minimal (average lengths for eight replicates of nonprimed, 7-d-primed, and 21-d-primed mericarps were 2.89 $\pm 0.13,2.68 \pm 0.08$, and $2.82 \pm 0.11 \mathrm{~mm}$, respectively), endosperm volume for 7-d-primed mericarps was unexpectedly low. This may have been due to degradation of endosperm during the priming process. Similar volumes for nonprimed and 21-dprimed central endosperm (Table 2) may have been due to cell wall expansion resulting in increased cell size during long-term priming; however, this remains speculative as no detailed cell size measurements were taken. Also, weight differences between mericarps from different umbel positions (Thomas, 1996) may result in volume variation in a commercially purchased mericarp lot. The sequence of endosperm cell degradation is related to the location of digestive enzymes present within the seed (Werker, 1997). Celery endosperm degradation may originate from embryoderived gibberellic acid that signals the endosperm to produce autolytic enzymes resulting in a centripetal pattern of endosperm degradation (Jacobsen and Pressman, 1979). Dawidowicz-Grzegorzewska (1997) and Dawidowicz-Grzegorzewska and Maguire (1993) observed that carrot endosperm changes during priming were limited to regions near the radicle. The sequence of central endosperm mobilization was centrifugal (radial progression of endosperm digestion), with cells nearest the embryo digested first. Cell walls of primed central endosperm were depleted to the extent that only inner walls of the central endosperm cell wall remained and, consequently, intercellular spaces formed in place of digested endosperm wall (Fig. 2D). The inner walls of 


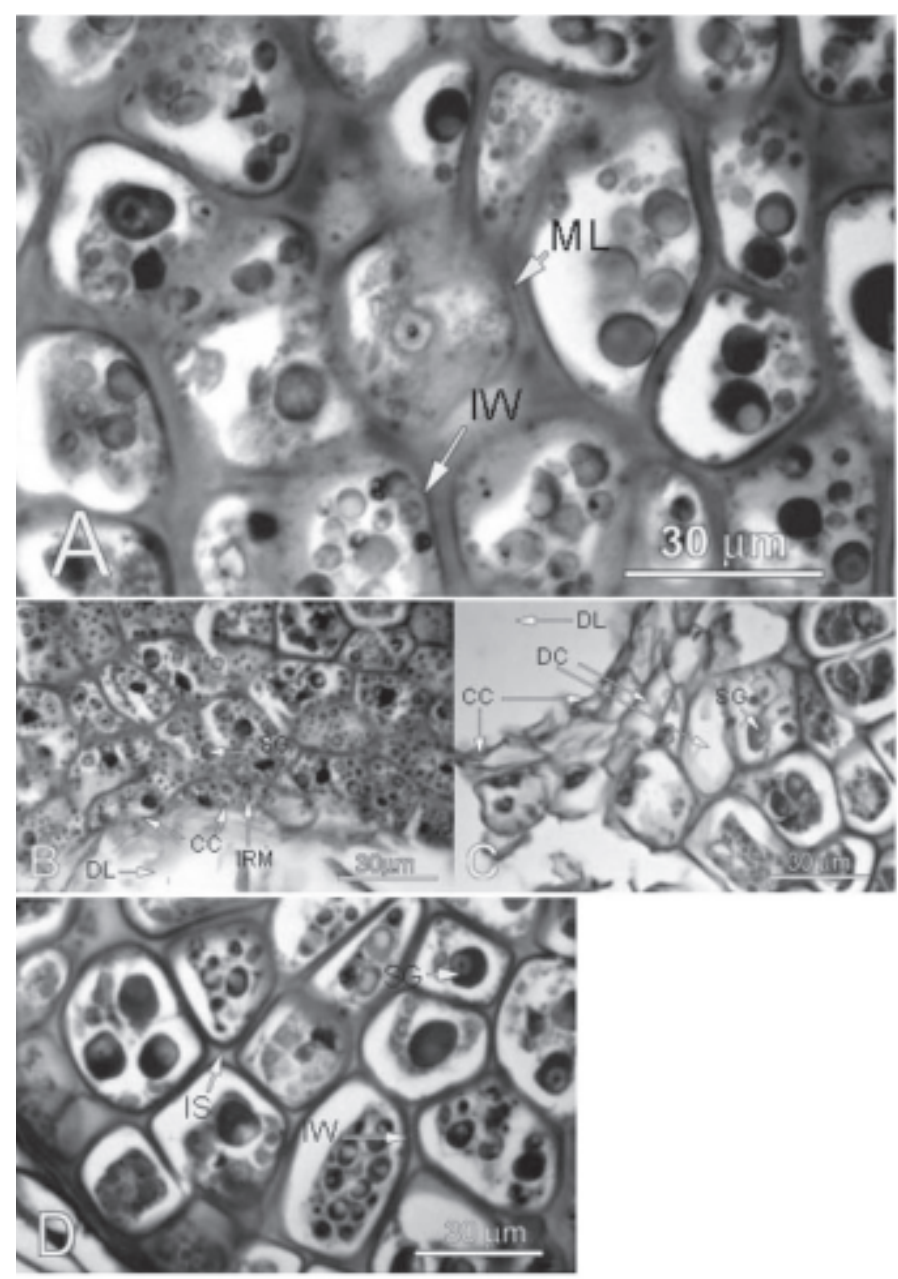

Fig. 2. Views of parsley endosperm. (A) nonprimed central endosperm cells were identified by large cell size, thick cell wall, and distinct middle lamellae, the nacreous nature (smeared appearance) is due to the thick primary cell wall; (B) nonprimed distal endosperm cells were identified by small cell size, thin cell wall, and irregular shape, the depleted layer is a space formation surrounding the embryo that likely becomes filled with water during hydration and may cause the compressed appearance of adjacent cells; (C) 21-d-primed distal endosperm illustrating the centripetal nature of digestion, with the initial digested cells being those nearest to the depleted layer and embryo and expanding in a radial direction; and (D) 21-d-primed central endosperm illustrating the results of thick cell wall digestion including complete digestion of materials between inner cell walls and intercellular space formation, starch grains were large in central endosperm but occurred in both distal and central endosperm. $\mathrm{CC}=$ compressed cell; $\mathrm{DC}=$ digested cell; $\mathrm{DL}=$ depleted layer; IRM = intracellular reserve materials; IS = intercellular space; $\mathrm{IW}=$ inner wall; $\mathrm{ML}=$ middle lamella; SG = starch grain.

adjacent cells came closer together as materials in the endosperm cell wall were depleted (Fig. 2D).

Distal endosperm cells adjacent the depleted layer contained intercellular reserve materials but following 21-d priming, and sometimes 7-d priming, cells were digested of their contents (Figs. $1 \mathrm{D}-\mathrm{F}$ and $2 \mathrm{~B}-\mathrm{C})$. Both before and after priming, cells adjacent to the depleted layer were crushed or compressed in appearance (Fig. 2B-C), possibly due to the force exerted by embryo growth and/or the water-filling of the cavity. Since many small seeded species contain no starch (Taylor, 1997) including carrot (Dawidowicz-Grzegorzewska, 1997), and transient amounts in celery (Jacobsen and Pressman, 1979), the presence of starch grains in parsley endosperm (Fig. 2B-D) and embryos (not shown) is surprising; however, the significance of this fact remains unknown. Although starch is often a temporary reserve material in many species (Werker, 1997) it was persistent in parsley (Fig. 2B-D). It is interesting to note that celery endosperm changes are light-dependent (Jacobsen and Pressman, 1979) while parsley endosperm changes occur in darkness.

We theorize that the increased germination rate of parsley mericarps with increasing priming duration could be attributed, in part, to greater radicle development that was dependent on the amount of endosperm storage cells that was mobilized for this purpose. Radicle development involved cell maturation since 24-h-imbibed primed mericarps had increased vacuolization, intercellular space formation and meristematic activity compared to 24-h-imbibed nonprimed mericarps (Olszewski, 2004). Associated with increased germination rate with extended priming, was an increase in depleted layer volume that may have been associated with increased mericarp moisture content, and a decrease in pericarp volume visible as degradation that may have reduced mechanical resistance to radicle penetration or may have eliminated germination inhibitors through a leaching effect.

\section{Literature Cited}

Akers, S.W., G.A. Berkowitz, and J. Rabin. 1987. Germination of parsley seed primed in aerated solutions of polyethylene glycol. HortScience 20:250-252.

Argerich, C.A. and K.J. Bradford. 1989. The effects of priming and aging on seed vigor in tomato. J. Expt. Bot. 40:599-608.

Austin, R.B., P.C. Longden, and J. Hutchinson. 1969. Some effects of 'hardening' carrot seed. Ann. Bot. 33:883-895.

Bozzola, J.J. and L.D. Russell. 1992. Electron microscopy: Principles and techniques for biologists. Jones and Bartlett, London.

Bradford, K.J. 1986. Manipulation of seed water relations via osmotic priming to improve germination under stress conditions. HortScience 21:1105-1112.

Brocklehurst, P.A. and J. Dearman. 1984. A comparison of different chemicals for osmotic treatment of vegetable seed. Ann. Appl. Biol. 105:391-398.

Dahal, P., K.J. Bradford, and R.A. Jones. 1990. Effects of priming and endosperm integrity on seed germination rates of tomato genotypes. I. Germination at suboptimal temperatures. J. Expt. Bot. 41:1431-1439.

Dawidowicz-Grzegorzewska, A. 1997. Ultrastructure of solid matrixprimed endospermic and nonendospermic seeds, p. 479-487. In: R.H. Ellis, M. Black A.J. Murdoch, and T.D. Hong (eds.). Basic and applied aspects of seed biology. Kluwer, Boston.

Dawidowicz-Grzegorzewska, A. and J.D. Maguire. 1993. The effects of SMP on the ultrastructure of carrot seeds. Proc. Fourth Intl. Wkshp. Seeds 3:1039-1044.

Dwarte, D. and A.E. Ashford. 1982. The chemistry and microstructure of protein bodies in celery endosperm. Bot. Gaz. 143:164-175.

Ely, P.R. and W. Heydecker. 1981. Fast germination of parsley seeds. Scientia Hort. 15:127-136.

Gray, D., J.R.A. Steckel, and L.J. Hands. 1990. Response of vegetable seeds to controlled hydration. Ann. Bot. 66:227-235.

Guedes, A.C., D.J. Cantliffe, and T.A. Nell. 1981. Morphological changes during lettuce seed priming and subsequent radicle development. J. Amer. Soc. Hort. Sci.106:121-126.

Hassell, R.L. and D.W. Kretchman. 1997. The effects of umbel order, soaking, and scarification on germination inhibiting substances in Petroselinum crispum L. and other Apiaceae seeds. HortScience 32:1227-1230.

International Seed Testing Association. 1985. International rules for seed testing. Seed Sci. Technol. 13:299-355.

Jacobsen, J.V. and E. Pressman. 1979. A structural study of germination in celery (Apium graveolens L.) seed with emphasis on endosperm breakdown. Planta 144:241-248. 
Jensen, W.A. 1962. Botanical histochemistry. Freeman, San Francisco. Kato, T., M. Kobayashi, N. Sasaki, and Y. Kitahara. 1978. The coumarin hereclenol as a growth inhibitor in parsley seeds. Phytochemistry 17:158-159.

Liptay, A. and N. Zariffa. 1993. Testing the morphological aspects of polyethylene glycol-primed tomato seeds with proportional odds analysis. HortScience 28:881-882.

Michel, B.E. and M.R. Kaufmann. 1973. The osmotic potential of polyethylene glycol 6000. Plant Physiol. 51:914-916.

Olszewski, M.W. 2004. The effects of priming on the anatomy, pathology and germination of parsley mericarps. PhD Diss. Univ. of Delaware, Newark.

Olszewski, M.W., W.G. Pill, and T.D. Pizzolato. 2004. Germination and embryo anatomy of osmotically primed parsley schizocarps. J. Amer. Soc. Hort. Sci. 129:876-880.

Parera, C.A., P. Qiao, and D.J. Cantliffe. 1993. Enhanced celery germination at stress temperature via solid matrix priming. HortScience 28:20-22.
Pill, W.G. 1986. Parsley emergence and seedling growth from raw, osmoconditioned and pregerminated seeds. HortScience 21:1134-1136.

Pill, W.G. 1995. Low water potential and presowing germination treatments to improve seed quality, p. 319-359. In: A.S. Basra (ed.). Seed quality: Basic mechanisms and agricultural implications. Haworlth Press, Binghampton, N.Y.

Pill, W.G. and E.A. Kilian. 2000. Germination and emergence of parsley in response to osmotic or matric seed priming and treatment with gibberellin. HortScience 35:907-909.

Taylor,A.G. 1997. Seed storage, germination, and quality, p. 1-36. In: H.C. Wien (ed.). The physiology of vegetable crops. CABI, New York.

Thomas, T.H. 1996. Relationships between position on the parent plant and germination characteristics of seeds of parsley (Petroselinum crispum Nym.). Plant Growth Regulat. 18:175-181.

Van der Toorn, P. 1989. Embryo growth in mature celery seeds. PhD Diss., Agr. Univ., Wageningen, The Netherlands.

Werker, E. 1997. Seed anatomy. Gebruder Borntraeger, Berlin, Germany. 